and Welfare, on the other hand, does fund some research more directly related to drug development and is actively promoting joint research between government researchers and industry and technology transfer from the government to the private sector.

In 1991, the foundation distributed $¥ 1,413$ million. Most of the money ( $¥ 1,090$ million) consisted of small grants of a few million yen to more than 400 researchers in national institutes, universities and private companies. The rest went to research fellowships for Japanese and foreign scientists in Japanese national institutes, overseas travel grants, seminars and symposia, surveys, and joint research with institutes overseas. The foundation also supports a joint programme to develop AIDS drugs, with a budget of $¥ 410$ million in 1991 .

There is, however, a darker side to some foundations funded by the pharmaceutical industry in Japan. It is common practice for powerful professors who have been involved in clinical trials to establish foundations on their retirement from university with donations from pharmaceutical companies. "Such foundations for clinical research are of questionable repute and help maintain the very poor level of clinical science in Japan", says Fukushima.

The pharmaceutical industry is, however, clearly trying to shed this dark image by investing more in basic research untied to drug development and sales. David Swinbanks

\title{
Looking towards the West
}

LONG content to develop and sell drugs in Japan, Japanese pharmaceutical companies have only recently begun to look to universities and other centres of research excellence overseas to develop new ideas, a trend that is likely to expand rapidly in coming years. The long-term objective of the companies is to develop new drugs by tapping into the expertise of Western scientists. But the move by Japanese companies is also providing a welcome influx of cash to the universities.

One of the first to set up a research laboratory on foreign soil was Otsuka Pharmaceutical Company which opened the Biomembrane Institute in Seattle near the campus of the University of Washington in 1987. The institute, a non-profit cancer research organization, has close links with the university. Several of the staff are tenured members of the university, and graduate students and university researchers freely use the institute's facilities.

Yamanouchi Pharmaceutical has

adopted a similar approach in establishing the Yamanouchi Research Institute, UK next door to the science park of the University of Oxford in 1990. Teruhisa Noguchi, executive vice president of Yamanouchi, says the company chose the Oxford site because "Britain is very strong in molecular biology and cell biology, has many Nobel prizewinners, and has strong medical research organizations, such as the Medical Research Council".

Noguchi says he hopes to make a "strategic research alliance" between Yamanouchi and the university. The company is funding a postdoctoral research fellowship at the university's Wolfson College, and company researchers, mainly British, at the institute are collaborating closely with university departments and research units, including the Institute of Molecular Medicine. Yamanouchi has just reorganized its main research institute in Tsukuba science city northeast of Tokyo, and three new laboratories of molecular

\section{LINKS BETWEEN JAPANESE PHARMACEUTICAL COMPANIES AND OVERSEAS UNIVERSITIES}

\begin{tabular}{|c|c|c|}
\hline $\begin{array}{l}\text { Company } \\
\text { Eisai }\end{array}$ & $\begin{array}{l}\text { University } \\
\text { University College London, UK }\end{array}$ & $\begin{array}{l}\text { Type of link } \\
\text { On-campus laboratory }\end{array}$ \\
\hline $\begin{array}{l}\text { Fujisawa } \\
\text { Pharmaceutical }\end{array}$ & University of Edinburgh, UK & On-campus institute \\
\hline $\begin{array}{l}\text { Yamanouchi } \\
\text { Pharmaceutical }\end{array}$ & University of Oxford, UK & Near-campus laboratory \\
\hline $\begin{array}{l}\text { Otsuka } \\
\text { Pharmaceutical }\end{array}$ & University of Washington, USA & Near-campus institute \\
\hline $\begin{array}{l}\text { Ono } \\
\text { Pharmaceutical }\end{array}$ & $\begin{array}{l}\text { 1) Kings College, London, UK } \\
\text { 2) William Harvey Institute, } \\
\text { St Bartholomews Hospital, UK }\end{array}$ & $\begin{array}{l}\text { Endowed chair } \\
\text { Endowed research }\end{array}$ \\
\hline $\begin{array}{l}\text { Daichi } \\
\text { Pharmaceutical }\end{array}$ & Vanderbilt University, USA & Endowed chair \\
\hline Shionogi & $\begin{array}{l}\text { Massachusetts Institute of } \\
\text { Technology, USA }\end{array}$ & Endowed grant \\
\hline
\end{tabular}

medicine at Tsukuba will interact closely with the Oxford institute, says Noguchi.

Other Japanese companies have formed even closer links to Western universities by setting up laboratories on university campuses. Two examples are the Eisai London Research Laboratories Ltd at University College London, and the Fujisawa Institute of Neuroscience at the University of Edinburgh.

The Eisai laboratory is housed in the top two floors of a seven-storey new building built and equipped by Eisai at a cost of $£ 12$ million. The university has plans to occupy the other two floors, and the director of laboratory, Lee Rubin, who was recruited from the United States, says he has encouraged very active interaction with other researchers in the university.

The laboratory focuses on diseases of the nervous system, in particular cell death in neurons. And Rubin says "I think in five years time we will have made significant progress in achieving some understanding of what goes on in neurons when they die and ways of stopping them, and that 10 years from now we will be in the position to point in the direction of possible new products". Eisai plans to invest about $£ 50$ million in the laboratory over the next 15 years and "is in it for the long term" says Rubin.

In the United States, Noguchi says that Yamanouchi plans a "more flexible, amoeba-like approach" to links with universities and venture businesses, and he does not intend to establish fixed organizations such as the UK institute in Oxford.

Shionogi is providing a large grant $(\$ 2$ million over 6 years) to Nobel prizewinner Susumu Tonegawa at Massachusetts Institute of Technology for his research on immunology. Daichi Pharmaceutical has donated $\$ 1.25$ million to Vanderbilt University Medical School in the United States for an endowed chair in clinical pharmacology. And Ono Pharmaceutical $\mathrm{Co}$. is pumping about $£ 1$ million a year into the William Harvey Institute at $\mathrm{St}$ Bartholomews Hospital in London to fund research in five areas related to inflammation of the arteries, tissue diseases (including rheumatoid conditions), cardiovascular diseases, the effect of hormones on inflammation and autoimmune diseases, and diabetes. The money supports 24 research staff and some support personnel at the institute.

The same company is donating $£ 100,000$ a year over five years to Kings College London to endow a chair in vascular biology, occupied by Jeremy Pearson. Pearson says this sum covers his salary and the costs of one research student. He says the company has put no restriction on his research and is keeping a relatively low profile.

David Swinbanks \& David Dickson 